\title{
Determinants of debt maturity structure across firm size
}

\begin{abstract}
This study examines the empirical determinants of debt maturity structure across the size of Spanish firms. Our evidence offers support for the relevance of size, asymmetric information and asset to maturity to explain the debt maturity structure. The paper also provides evidence relative to the differences in explanations according to firm size. It is shown that debt maturity in small firms is higher when the slope of the interest rate term structure increases and for very low-risk and very risky firms.
\end{abstract}

JEL classification: G32

Keywords: debt maturity, firm size, growth opportunities, asymmetric information, maturity of assets, taxes. 


\section{INTRODUCTION}

Capital structure research has traditionally focused on explaining the incentives that lead large public corporations to choose particular financing policies. There has been less research on other characteristics of debt financing, such as debt maturity structure. Theories of debt maturity have focused on the roles of agency costs (Myers, 1977; Barnea et al., 1980), asymmetric information (Flannery, 1986; Diamond, 1991) and taxes (Brick and Ravid, 1985; Lewis, 1990).

Empirical analysis has identified several factors that can affect a firm's choice of debt maturity structure. These factors include the firm's options for growth, the maturity of existing assets, the default risk, the level of asymmetric information, and the effective income tax rate of the firm. Barclay and Smith (1995), Stohs and Mauer (1996), Guedes and Opler (1996), and Ozkan (2000) have provided empirical evidence about the determinants of maturity structure of debt for large firms. Other papers have focused on small firms, such as Scherr and Hulburt (2001), and Berger et al. (2005) $)^{1}$. Antoniou et al. (2006) have examined the influence of the country's financial systems and institutional aspects, analyzing the determinants of the debt maturity structure of French, German and UK firms.

The evidence provided by these papers is mixed. Barclay and Smith (1995), Guedes and Opler (1996) and Ozkan (2000) provide strong support for the hypothesis that firms with more growth opportunities in their investment sets tend to have more shorter-term debt. In line with Diamond's (1991) prediction, Barclay and Smith (1995), Stohs and Mauer (1996) and Scherr and Hulburt (2001) find evidence of a nonmonotonic relationship between debt maturity structure and credit quality. ${ }^{2}$ The

\footnotetext{
${ }^{1}$ This paper only tests the implications of the models of Flannery (1986) and Diamond (1991) concerning the effects of asymmetric information.

${ }^{2}$ Barclay and Smith (1995) and Stohs and Mauer (1996) use a bond rating variable based on a firm's S\&P bond rating, while Scherr and Hulburt (2001) use Altman's Z score (1968) as a measure of default risk, seeing as the debt of small firms is not rated.
} 
evidence also provides strong support for the maturity-matching hypothesis, which predicts that firms match the maturity of their debt to that of their assets.

Cuñat (1999) has provided evidence on the determinants of the maturity structure for a sample of 227 Spanish listed firms in the period 1983-1994. His results show that firms with higher growth opportunities shorten the maturity of their debt significantly, although there is no evidence in favor of signaling or tax models. Additionally, bigger firms and those with a greater degree of government participation present a higher maturity. Although this author also analyses the existence of an effect of size in the determinants of debt maturity, he uses only listed firms. More recently, two papers have analyzed the determinants of debt maturity in Spanish SMEs. García-Teruel and Martínez-Solano (2007) analyze the debt maturity structure of small and medium-sized firms in terms of the risk and return trade-off associated with the use of short-term debt (Jun and Jen, 2003). López-Gracia and Mestre-Barberá (2011) analyze the influence of the tax effect on SME debt maturity structure.

Within this context, the present paper examines the factors that Spanish firms take into consideration when choosing the maturity of their debt, analyzing whether the validity of the agency cost hypothesis, the signaling hypothesis, the maturitymatching hypothesis and the tax hypothesis varies according to firm size. The main contribution of the paper is that of analyzing the relevance of these explanations jointly for a large sample of small, medium-sized and large firms. As far as we know, there are no papers that have tested the validity of these explanations on a single sample that includes both large and small firms. Considering a single sample allows us to test the existence of a different validity for each of the explanations proposed in the literature in accordance with firm size.

The results highlight the relevance of size, signaling and asset maturity explanations in explaining debt maturity. The firm's options for growth, however, have no effect on its debt maturity structure. Moreover, the main difference when 
considering firm size is the existence of lower validity with respect to the predictions of Diamond's (1991) model for small firms.

The rest of the paper is organized as follows. Section 2 discusses the validity of theoretical arguments as determinants of debt maturity. Section 3 describes the characteristics of the database and methodology employed, while Section 4 discusses the empirical results. Finally, Section 5 concludes the paper.

\section{THEORETICAL BACKGROUND AND HYPOTHESES}

Four non-mutually exclusive hypotheses have been put forward to explain corporate debt maturity structure: asset maturity, agency costs, asymmetric information and taxes. In what follows, we summarize these explanations, which are then tested by the empirical model.

\subsection{ASSET MATURITY}

Firms match their debt maturities to their asset maturities. If the maturity of debt is shorter than that of assets, the firm may not have sufficient cash available to pay its financial obligations when they are due. However, if debt has a longer maturity, the debt payments remain due when the cash flows from assets cease. Matching the maturities of assets and debt reduces these risks. Myers (1977) argues that the underinvestment problem can be mitigated by matching the maturity of liabilities and assets. Therefore, a positive relationship is expected between debt maturity and asset maturity.

\subsection{AgENCY COSTS}

The agency costs of debt may influence corporate debt maturity. Agency costs give rise to an underinvestment problem. When a firm has future options for growth via a profitable investment opportunity set, the existence of risky debt in the capital structure means that the benefits from undertaking profitable investment projects 
will go only partly to shareholders. Debtholders will share the benefit, because the probability of default is reduced by the investment projects. Since the benefit goes partly to debtholders, shareholders have incentives to reject positive net present value projects, thus leading to what is known as the underinvestment problem.

Myers (1977) argues that a firm may control this underinvestment incentive by shortening the effective maturity of its debt, in such a way that debt matures before growth options are exercised. This explanation of debt maturity (called the agency-cost or contracting-cost hypothesis) suggests that firms whose value depends to a large extent on investment opportunities have an incentive to borrow short-term. Several papers have provided favorable evidence for this relationship, such as Barclay and Smith (1995), Guedes and Opler (1996) or Ozkan (2000).

Agency problems between shareholders and debtholders may be particularly severe for small firms as a consequence of risk shifting and claim dilution (Smith and Warner, 1979). Smaller firms are less able to access capital markets (Titman and Wessels, 1988) and long-term debt markets seeing as the ratio of their collateralizable assets to future investment opportunities is relatively small (Whited, 1992). Moreover, smaller firms are less able to issue public debt because they have a large fixed component of issuance costs. Like Myers (1977), Barnea et al. (1980) suggest that these problems may be reduced by issuing shorter-term debt. These arguments thus suggest that debt maturity varies directly with firm size.

\subsection{ASYMMETRIC INFORMATION}

Diamond (1991) provides a model to explain why risky firms with long-term projects might use short-term debt under the existence of asymmetric information. Firms with favorable private information and low-risk (high credit ratings) may choose short-term debt at relatively low interest rates because the refinancing risk is small. Firms with favorable private information and intermediate risk may choose long-term debt at a higher rate to reduce their greater liquidity risk of being unable 
to refinance the debt if they choose short-term debt. Since short-term borrowing exposes firms to the risk of excessive liquidations, firms with high-risk (low credit ratings) prefer long-term debt so as to reduce this refinancing risk. Firms with higher default risk may be unable to borrow long-term because of the high probability of bad projects. Thus, Diamond's (1991) model predicts debt maturity to have a nonmonotonic relation with risk ratings. Very low-risk firms and very risky firms borrow short-term and firms with intermediate risks are more likely to borrow long-term.

Several studies analyze the relationship between debt maturity and risk ratings. Barclay and Smith (1995) show a nonmonotonic relation between debt maturity and bond ratings. Firms with higher bond ratings tend to have more short-term debt than those with lower bond ratings. Firms without bond ratings have more short-term debt. More recently, Stohs and Mauer (1996) and Scherr and Hulburt (2001) also provide results in line with Diamond's (1991) predicted nonmonotonic relationship.

\subsection{TAXES}

Brick and Ravid $(1985,1991)$ argue that the expected value of tax benefits depends on the maturity of debt when the term structure of interest rates is not flat, since the firm can default on its promised debt payments. Firms increase their value by increasing the amount of long-term debt. This is due to the fact that the interest tax shield on debt is accelerated by increasing the proportion of debt payments allocated to long-term debt. Similarly, Kim et al. (1995) demonstrate that a long-term debt maturity strategy maximizes investor tax-timing option value $^{3}$. Consequently, debt maturity should vary directly with the slope of the term structure.

\footnotetext{
${ }^{3}$ However, Lewis (1990) argues that taxes have no effect on optimal debt maturity if optimal leverage and debt maturity are chosen simultaneously.
} 
Kane et al. (1985), on the other hand, show that the trade-off between bankruptcy cost and the costs of raising debt and the per-period tax-advantage of debt financing leads to an optimal debt maturity structure. These authors demonstrate that optimal debt maturity is negatively related to the tax advantage of debt. The empirically testable hypothesis is that a firm's debt maturity increases as its effective tax rate decreases.

Little favorable evidence has been shown for the tax hypothesis, receiving mixed support in Stohs and Mauer (1996). These authors find a negative relation between tax rate and debt maturity as predicted, although there is no evidence that the debt maturity structure is positively related to the slope of the term structure. Barclay and Smith (1995), Guedes and Opler (1996) and Ozkan (2000), on the other hand, find no evidence for the tax hypothesis.

\section{ECONOMETRIC SPECIFICATION AND DATABASE}

We use the following model to investigate the determinants of the debt maturity structure of firms:

$$
\begin{aligned}
& \text { DEBTMAT }_{i t}=a_{0}+a_{1} \text { GROWTH }_{i t}+a_{2} \text { SIZE }_{i t}+a_{3} \text { DEFAULTRISK }_{i t}+ \\
& a_{4} \text { ASSETMAT }_{i t}+a_{5} \text { TERMPREMIUM }_{t}+a_{6} \text { TAXEXP }_{i t}+\sum_{t=1995}^{2006} Y_{t}+v_{i}+\varepsilon_{i t}
\end{aligned}
$$

where DEBTMAT is the debt maturity of firm $i$ in the year $t$ and the determinants are agency costs (GROWTH and SIZE), credit quality (DEFAULTRISK), maturity of

assets (ASSETMAT), and taxation (TERMPREMIUM and TAXEXP). $\sum_{t=1995}^{2006} Y_{t}$ is a set of dummy time variables for each year that capture any unobserved firm-invariant time effect not included in the regression, $v_{i}$ is the firm effect, which is assumed constant for firm i over $t$, and $\xi_{\text {it }}$ is the error term.

To test the empirical determinants of debt maturity, we use a sample of Spanish firms during the period 1995-2006. The data come from SABI and consist of 
financial statement data and ratios for over a million Spanish companies. We select non-financial corporations (firms with SIC 6000-6999 have been excluded) that have (1) more than 10 employees, and (2) data throughout the 12-year sample period to construct the variables used. We exclude firms reporting zero debt. Finally, the sample is made up of 39,603 corporations and 246,344 observations, although the number of observations varies depending on the variables used.

SABI reports the amount of long-term debt payable in one year. To measure the maturity structure of a firm's debt (DEBTMAT), we examine the percentage of the firm's total debt (long-term debt plus debt in current liabilities) that has a maturity of more than one year. Prior studies have used various measures of debt maturity, considering either a balance sheet approach or an incremental approach. Examples of the balance sheet approach are Scherr and Hulburt (2001), Barclay and Smith (1995) or Ozkan (2000). Scherr and Hulburt (2001) use two specifications, longterm debt payable after one year to total debt, as in this paper, and weightedaverage debt maturity, reporting that differences in results between the two specifications of debt maturity are minor; Barclay and Smith (1995) use the percentage of long-term debt payable after three years to total debt; while the dependent variable in Ozkan (2000) is the ratio of debt that matures in more than five years to total debt.

Guedes and Opler (1996) and Berger et al. (2005), on the other hand, use an incremental approach. Guedes and Opler (1996) consider the maturity of debt issues as the dependent variable, while Berger et al. (2005) use a sample on new loans to small businesses. The argument for using the maturity of new issues is that some questions about the determinants of debt maturity, such as signaling models of maturity choice, can only be properly tested using the incremental approach. However, the incremental approach is not well suited to testing theories that relate asset maturity to the average of the maturities of the firm's existing 
liabilities, since the term-to-maturity of an individual issue only provides information about incremental financing choices.

We use a balance sheet approach in the present paper. This is driven primarily by the nature of the sample. Seeing as we are concerned with whether there are differences among the determinants of corporate debt maturity structure according to firm size, we need a dependent variable that can be measured for firms of any size. The balance sheet approach allows us to use a measure of debt maturity common to all firms. Moreover, the debate concerning the use of a balance sheet or incremental approach is of less importance in Spain. Garcia-Teruel and MartínezSolano (2007) show a high proportion of short-term debt with respect to total debt. For their sample of 11,533 small and medium-sized firms, $80.81 \%$ of total debt is short-term debt. We also find a high percentage of short-term debt in our sample, as will be seen in Table 1 . If debt is mainly short-term, the limitations related to maturity structure approximation based on the ratio of long-term debt to total debt are less relevant.

Growth options have usually been proxied by the market-to-book ratio (Barclay and Smith, 1995; Guedes and Opler, 1996; Stohs and Mauer, 1996; and Ozkan, 2000). Seeing as we consider non-quoted firms, it is not possible to measure a firm's growth opportunities by the market-to-book ratio, as is usual in other papers. A way of measuring a firm's growth opportunities (GROWTH) is to assess its past growth, assuming that firms that grow faster also have greater opportunities for future growth. We measure the ratios of current sales divided by prior sales (SALESGROWTH) and current assets divided by prior assets (ASSETGROWTH) to capture past growth. We also use the ratio of depreciation to total assets (DEPREC_TA) to measure the weight of intangibles, as in Scherr and Hulburt 
(2001). ${ }^{4}$ Size, on the other hand, is measured as the natural logarithm of firm assets (LNASSETS) in constant 1995 thousands of euros.

The predictions of Diamond's (1991) model have usually been tested by using bond ratings to measure default risk, as in Barclay and Smith (1995), Guedes and Opler (1996), and Stohs and Mauer (1996). As our database includes small firms whose debt is not rated, we have used Altman's Z score (1968) as a measure of default risk (DEFAULTRISK) following Scherr and Hulburt (2001). Altman's Z score is computed using five accounting ratios, with high values indicating a low probability of default:

$$
Z=1.2 X_{1}+1.4 X_{2}+3.3 X_{3}+0.6 X_{4}+1.0 X_{5}
$$

where:

$\mathrm{X}_{1}=$ (current assets-current debt) / total assets

$\mathrm{X}_{2}=$ retained earnings $/$ total assets

$\mathrm{X}_{3}=$ earnings before interest and taxes / total assets

$\mathrm{X}_{4}=$ equity / total debt

$\mathrm{X}_{5}=$ sales $/$ total assets

To test the nonmonotonic relationship between default risk and debt maturity predicted in Diamond's model, we create two dummy variables. HIGH DEFAULT equals one if the firm has a negative value for the $Z$ score, and zero otherwise; while LOW DEFAULT equals one if the $Z$ score is above the $66^{\text {th }}$ percentile, and zero otherwise.

For the empirical test of the maturity matching, asset maturity (ASSETMAT) is computed by means of the ratio between property, plant and equipment and the annual depreciation (PPE_DEPREC). The idea underlying this measure is that longer

\footnotetext{
${ }^{4}$ Another alternative is to consider the $\mathrm{R} \& \mathrm{D}$ expenses to total sales to measure growth-oriented investments. The number of firms for which we have this information drops considerably, providing only 11,886 observations. The results for this variable are not significant.
} 
maturity assets will depreciate at a slower rate. ${ }^{5} \mathrm{~A}$ similar definition has been used by Ozkan (2000).

To test the tax hypothesis, we measure the term structure of interest rates as the difference between the month-end yield on ten-year government bonds and the month-end yield on six-month government bonds (TERMPREMIUM). The data are obtained from the database provided by the Central Bank of Spain. To measure the effective tax rate, we use the ratio of income tax expense to total assets (TAXEXP) (Guedes and Opler, 1996).

We have split the sample into small, medium-sized and large enterprises applying the criteria of firm size defined by the European Union in the Commission Recommendation of $3^{\text {rd }}$ April $1996(96 / 280 / E C) .{ }^{6}$ A small firm is defined as an enterprise that has fewer than 50 employees but more than 10, and has either an annual turnover not exceeding seven million euros or an annual balance-sheet total not exceeding five million euros. Medium-sized firms are defined as enterprises that have between 50 and 249 employees, and have either an annual turnover not exceeding 40 million euros, or an annual balance-sheet total not exceeding 27 million euros. Firms that exceed these limits are considered large enterprises.

Table 1 presents mean values for debt maturity and independent variables. The first aspect worth highlighting is the low long-term debt of the sample of Spanish firms. Barclay and Smith (1995) report a percentage of total long-term debt of around $70 \%$, versus $23.49 \%$ for the sample under study shown in Table 1 . The division of the sample into small, medium-sized and large firms does not reflect significant differences in the percentage of total debt according to firm size.

\footnotetext{
${ }^{5}$ Similar results are obtained when the variable PPE_DEPREC is multiplied by the ratio between property, plan, and equipment and total assets.

${ }^{6}$ This criteria was the one in force during the period covered by our study. On $6^{\text {th }}$ May 2003, the Commission adopted a new Recommendation (2003/361/EC) regarding the definition of SMEs which replaced Recommendation $96 / 280 / \mathrm{EC}$ as from $1^{\text {st }}$ January 2005 . We have found that the results do not vary with the new classification of firm size.
} 
However, the percentage of long-term debt is large in small firms compared to large and medium-sized firms.

\section{INSERT TABLE 1 ABOUT HERE}

The sample under study presents very high mean values of SALESGROWTH and ASSETGROWTH, especially for large firms. However, these mean values are altered by the existence of a small number of outliers. The median values for SALES GROWTH (ASSET GROWTH) are thus $6.99 \%(6.90 \%), 6.13 \%(6.17 \%), 8.16 \%$ $(8.06 \%)$, and $9.40 \%(8.72 \%)$ respectively for the total sample, small, mediumsized and large firms. According to the mean values of the DEFAULT RISK variable, large and medium-sized firms have higher default risk than small firms.

Table 2 illustrates the relation between Altman's Z score and debt maturity for the total sample and for small, medium-sized and large firms. As we can see in Table 2, the values of the ratio of total debt to total assets and the ratio of earnings before interest and taxes plus depreciation expenses to total assets corroborate the classification of default risk obtained for Altman's Z score. It can be observed that the level of total debt decreases with firm solvency, while profitability grows as solvency improves according to Altman's Z score. The firms belonging to the lower solvency group $(Z<0)$ present a mean proportion of total debt to assets of $121.96 \%$ and a profitability of $-24.22 \%$. However, for the group made up of the more solvent firms $(Z \geq 7)$, the level of total debt is situated at $35.26 \%$ and profitability at $19.82 \%$. Moreover, the ratio of total debt to assets is monotonically decreasing according to Altman's Z score, whereas profitability is monotonically increasing. This shows the validity of Altman's Z score as a proxy of the financial strength of Spanish firms.

\section{INSERT TABLE 2 ABOUT HERE}

As regards the analysis of the relation between debt maturity and default risk, it can be seen in Panel A in Table 2 that the mean value of long-term debt decreases 
from a value of $39.00 \%$ for $Z$ values between 0 and 1 to $18.28 \%$ for $Z$ values above 7. Furthermore, the mean percentage of long-term debt for $Z$ values below zero (firms with very high-risk) is $31.59 \%$. These results are partially consistent with Diamond's (1991) model since the average debt maturity is lower for firms with high default probabilities and for firms with low default probabilities with respect to firms with intermediate-range default probabilities. The firms with high risk, and consequently more debt maturity, are only those with negative values of Z. This relationship between default risk and debt maturity is similar to that obtained by Scherr and Hulburt (2001) for a sample of US small firms. The main difference is that firms with an Altman's $Z$ score higher than two have less percentage of long-term debt than the average (20.78\% versus $23.49 \%$ ), whereas Scherr and Hulburt (2001) show that firms with a Z score higher than six are the ones that have less debt than the average (43.5\% versus $44.31 \%)$.

This fulfilling of the predictions based on Diamond's model (1991) is maintained when firm size is taken into account (Panels B, C and D in Table 2). The breakdown of the sample into subgroups according to firm size following the criteria of European Commission Recommendation 96/280/EC provides similar results to those already reported for the total sample. Small, medium-sized and large firms with low risk have lower than average long-term debt. Very high risk firms $(Z<0)$, on the other hand, have less long-term debt than firms that present an intermediate risk situation $(0 \leq Z<1)$.

Table 3 reports the correlation matrix. According to the arguments of asset maturity, debt maturity is positively correlated with the ratio between property, plant and equipment and the annual depreciation. The correlation of debt maturity with default risk is negative, highlighting less long-term debt as the solvency of the firm increases. The correlation between debt maturity and the tax rate is negative, in line with the arguments of Kane et al. (1985). The independent variables do not 
present high correlations with one another, except for the variables used to measure the firm's growth opportunities, i.e., sales and asset growth.

\section{INSERT TABLE 3 ABOUT HERE}

\section{RESULTS}

Debt maturity explanations are tested using panel data. Prior to testing, we use the Breusch-Pagan test (Breusch and Pagan, 1980) to identify the existence of individual effects. The null hypothesis of no unobserved heterogeneity is rejected. The Hausman test (1978) indicates that only the within-group estimation is consistent.

Table 4 reports the results of the determinants of debt maturity structure. In a way that is inconsistent with the agency cost hypothesis, the coefficients estimated on the growth of sales [column (1)] and the growth of assets [column (2)] are not significant. This finding is in line with Stohs and Mauer (1996) and Scherr and Hulburt (2001), who do not find support for the prediction that debt maturity structure is inversely related to growth options. However, the ratio of depreciation to total assets [column (3)] has the expected sign. This ratio measures investment in fixed assets, which we expected to be negatively related to growth opportunities. Thus, firms that have more conflicts between shareholders and debtholders use a higher proportion of short-term debt to mitigate these conflicts. We find mixed results for the prediction that the debt maturity structure decreases as the proportion of growth options in the firm's investment opportunity set increases. In keeping with the validity of the agency costs hypothesis, Cuñat (1999) finds that firms with higher growth opportunities shorten the maturity of debt. Our evidence should be interpreted with some caution due to the difficulties in correctly estimating growth opportunities as a result of not being able to use the market-tobook ratio as a measure. 
The coefficients on size (LNASSETS) are positive in all the estimations. This means that larger firms have longer debt maturity structures. This result is consistent with the role of short-term debt in reducing agency problems between shareholders and debtholders that might be particularly severe for small firms. Barclay and Smith (1995), Stohs and Mauer (1996) and Ozkan (2000) also provide evidence along these lines. To measure the economic significance of the influence of firm size on debt maturity structure, we estimated the percent change in the dependent variable that results from a one standard deviation change in the explanatory variable. Considering the coefficient on size in column (4) in Table 4, one standard deviation increase in size raises debt maturity by $35.28 \%$.

In columns (1) to (3) in Table 4, we report a significant and positive relation between firm quality and debt maturity. Seeing as an increase in Z corresponds to a reduction in default probability, this positive coefficient is in line with the use of longer-term debt when the default risk decreases. To test the implications of Diamond's (1991) model, we build two dummy variables according to the level of default risk. The first dummy variable is HIGH DEFAULT, which takes a value of one if the firm has a negative value for Altman's Z score, and zero otherwise. LOW DEFAULT is the second dummy variable and equals one if Altman's Z score is above the $66^{\text {th }}$ percentile, and zero otherwise.

The results are shown in columns (4) to (6) in Table 4. The two dummy variables are significant and negative. These coefficients reveal that firms belonging to the category with the lowest credit score as well as those with the highest credit score borrow on a shorter term. This result is consistent with the nonmonotonic relation between debt maturity and default risk and provides evidence that is favorable to the implications of Diamond's (1991) model. The coefficients in column (4) indicate that, all else being equal, debt maturity structure decreases by $2.37 \%$ and $8.66 \%$ respectively for a one standard deviation in HIGH DEFAULT and LOW DEFAULT. 
The proxy for the asset maturity of firms, i.e., the ratio of net property, plant and equipment to annual depreciation expense, presents a positive and significant coefficient. Firms with longer-lived assets use longer-maturity debt. This implies support for the maturity-matching hypothesis, although the economic significance of the influence of asset maturity on debt maturity structure is only $0.39 \%$. Cuñat (1999) also shows weak evidence on firms matching their debt maturities to their asset maturities.

We find mixed evidence for the tax hypothesis. On the one hand, the tax hypothesis predicts an inverse relationship between debt maturity structure and the ratio of taxes paid to assets (TAX EXP). In line with this prediction, the coefficient of TAX EXP shown in Table 4 is negative and significant. From the coefficient in column (4), a one standard deviation in the ratio of taxes paid to assets decreases debt maturity by $6.34 \%$.

On the other hand, there is no clear evidence that debt maturity is positively related to the slope of term structure (TERM PREMIUM). The relationship between TERM PREMIUM and DEBTMAT is positive and significant only when growth opportunities are measured as the ratio of current sales divided by prior sales (SALES GROWTH). In this case, this finding would imply favorable evidence for this hypothesis. However, when growth opportunities are measured by ASSET GROWTH or DEPREC_TA, there is a negative and significant association between the term premium and debt maturity ${ }^{7}$. As a consequence of these contradictory results, our findings might be seen as providing modest support for the tax hypothesis. Whatever the case may be, the economic impact of this variable in the dependent variable is never higher than $1.67 \%$.

\footnotetext{
${ }^{7}$ This negative relationship between term premium and debt maturity was also the result obtained by Guedes and Opler (1996).
} 
The findings for growth opportunities, maturity of assets and tax explanation are similar to those commented above when the dummy variables in columns (4) to (6) are used to test the predictions of Diamond's (1991) model.

\subsection{DeterminantS OF FIRM DEBT MATURITY ACCORDING TO SIZE}

Tables 5 and 6 show the findings regarding the determinants of debt maturity structure according to firm size. The sample has been split applying the criteria defined by the European Union in Commission Recommendation 96/280/EC. Firstly, the basic model tested in Table 4 for the entire sample is applied in Table 5 to the three subsamples of small, medium-sized and large firms. Secondly, the results for the different validities of the explanations are shown in Table 6, where these are analyzed using interaction variables between the independent variables and the dummy variable SMALL. In columns (1) to (3), the dummy variable SMALL takes the value of 1 if the firm is a small-sized firm according to EU criteria, and zero otherwise. In columns (4) to (6), the dummy variable SMALL takes the value of 1 if the firm is a small or medium-sized firm according to EU criteria, and zero otherwise. These interaction terms allow us to analyze whether the determinants of debt maturity are equally valid in small firms versus medium-sized and large firms. For the sake of brevity, only the results obtained in columns (1) to (3) in Table 6 are commented.

\section{INSERT TABLES 5 AND 6 ABOUT HERE}

The results for the independent variables of the basic model are similar to those reported in Table 4. Evidence favorable to the expected relationships is found for the asymmetric information and maturity of assets hypotheses and mixed evidence for the agency costs and tax hypotheses. Since these findings have been highlighted previously, our comments focus here on the interaction terms.

Our findings show that the main difference when comparing firms according to their size is the existence of a different effect of asymmetric information in smaller firms 
versus medium-sized and large firms. The variables SMALL*HIGH DEFAULT and SMALL*LOW DEFAULT present a positive and significant coefficient. This sign underscores the presence of greater long-term debt for small firms that have very high or very low risk. Thus, although the predictions of Diamond's (1991) model are fulfilled in smaller firms, they are fulfilled to a greater extent in large firms. This difference disappears almost completely when considering the differential effect of small and medium-sized firms versus large firms [columns (4) to (6)].

The differential effect of the interest rate term structure on smaller firms reveals that these firms consider term structure to be an important determinant of debt maturity. Only the debt maturity of smaller firms varies directly with the slope of the term structure of interest rates. For large firms, term structure has a negative influence on debt maturity. There is no differential effect, however, of tax expenses on debt maturity according to firm size.

The estimations do not provide strong support for the agency cost hypothesis, the maturity-matching hypothesis or the tax-based hypothesis as explanations that vary between firms according to their size. No difference seems to exist in the validity of the agency cost explanation seeing as the coefficients SMALL*SALES GROWTH and SMALL*ASSET GROWTH are not significant. This shows that there is no differential effect of these variables that measure the growth opportunities on debt maturity according to firm size. However, a difference does exist if the growth opportunities are measured as the ratio of depreciation to total assets. The coefficient of SMALL*DEPREC_TA is positive. This suggests that smaller firms with more investment in tangible assets have longer-term debt, thus providing favorable evidence for the hypothesis that smaller firms with more growth opportunities control suboptimal investment incentives by shortening the maturity of their debt.

The maturity matching hypothesis only shows the existence of a differential effect for smaller firms in some estimations of Table 6 , highlighting the greater validity of 
matching the maturity of assets and debt to reduce the risks of refinancing and liquidity in small firms.

\section{CONCLUSIONS}

In this paper, the empirical determinants of a firm's debt maturity structure are examined for a sample of 39,603 non-financial Spanish firms over the period 19952006. The main contribution of the paper consists in analyzing the different validity of the empirical determinants of debt maturity structure for small, medium-sized and large firms.

Our results show the relevance of size, asymmetric information and asset maturity in explaining debt maturity. Our findings are not significantly different to those reported for US firms. The main difference with respect to the institutional environment arises from the maturity of debt and not from the determinants. Spanish firms present a lower ratio of long-term debt to total debt compared to US firms. We find mixed evidence in line with the agency cost perspective that debt maturity is used to control conflicts of interest between shareholders and debtholders. On the one hand, smaller firms tend to use shorter-term debt. On the other, there is no support for the prediction that debt maturity is inversely related to proxies for growth opportunities. These mixed results are similar to those found by Stohs and Mauer (1996) or Scherr and Hulburt (2001) for US firms. We obtain evidence consistent with Diamond's (1991) prediction of a nonmonotonic relation between debt maturity structure and probability of default. This result has been highlighted by Stohs and Mauer (1996) and Guedes and Opler (1996). We also find evidence in favor of the asset maturity explanation, as in Scherr and Hulburt (2001) and Stohs and Mauer (1996) for US firms or Ozkan (2000) for UK firms.

Like Cuñat (1999), we provide evidence in favor of the asset maturity hypothesis and no clear support for tax arguments, the differences residing in the influence of growth opportunities and asymmetric information. As regards the effect of growth 
opportunities, our result should be considered with caution, since we are not able to use the market-to-book ratio to measure firm growth opportunities. Cuñat (1999) finds that smaller firms tend to use shorter-term debt, as do we. However, this evidence is obtained considering only listed firms. García-Teruel and MartínezSolano (2007) show more solvent firms using higher proportional short-term debt, as do we. However, we also show that firms with the lowest credit score borrow on a shorter term.

We likewise provide evidence relative to the differences in the explanations according to firm size. We show that the term structure of interest rates and the probability of default are the determinants that have a differential influence between small and large firms. Debt maturity in smaller firms is higher when the slope of the interest rate term structure increases and for very low-risk and very risky firms. This last result implies that the prediction of Diamond's (1991) model is fulfilled to a greater extent in large firms than in smaller firms.

\section{REFERENCES}

Altman, E.I., 1968. "Financial ratios, discriminant analysis and the prediction of corporate bankruptcy". The Journal of Finance, 23 (4), 589-609.

Antoniou, A., Y. Guney and K. Paudyal, 2006. "The determinants of debt maturity structure: evidence from France, Germany and the UK". European Financial Management, 12 (2), 161-194.

Barclay, M.J., L.M. Marx and C.W. Smith, 2003. "The joint determination of leverage and maturity". Journal of Corporate Finance, 9 (2), 149-167.

Barclay, M.J. and C.W. Smith, 1995. "The maturity structure of corporate debt". The Journal of Finance, 50, 609-631.

Barnea, A., R.A. Haugen, R.A. and L.W. Senbet, 1980. "A rationale for debt maturity structure and call provisions in the agency theoretic framework". The Journal of Finance, 35 (5), 1223-1234.

Berger, A.N., M.A. Espinosa-Vega, W.S. Frame and N.H. Miller, 2005. "Debt maturity, risk, and asymmetric information". The Journal of Finance, 60 (6), 2895-2923.

Breusch, T. and A. Pagan, 1980. "The LM Test and its applications to model specification in econometrics". Review of Economic Studies, 47 (1), 239-254.

Brick, I.E. and S.A. Ravid, 1985. "On the relevance of debt maturity structure". The Journal of Finance, 40 (5), 1423-1437.

Brick, I.E. and S.A. Ravid, 1991. "Interest rate uncertainty and the optimal debt maturity structure". Journal of Financial and Quantitative Analysis, 26, 6381. 
Cuñat, V., 1999. "Determinantes del plazo de endeudamiento de las empresas españolas". Investigaciones Económicas, 23 (3), 351-392.

Demirgüç-Kunt, A. and V. Maksimovic, 1999. "Institutions, financial markets, and firm debt maturity". Journal of Financial Economics, 54, 295-336.

Diamond, D.W., 1991. "Debt maturity structure and liquidity risk". Quarterly Journal of Economics, 106, 709-737.

Fan, J.P.H., S. Titman and G. Twite, 2006. "An international comparison of capital structure and debt maturity choices", AFA 2005 Philadelphia Meetings Available at SSRN: http://ssrn.com/abstract $=423483$.

Flannery, M.J., 1986. "Asymmetric information and risky debt maturity choice". The Journal of Finance, 41 (1), 19-37.

García-Teruel, P.J. and P. Martínez-Solano, 2007. "Short-term debt in Spanish SMEs". International Small Business Journal, 25 (6), 579-602.

Guedes, J. and T. Opler, 1996. "The determinants of the maturity of corporate debt issues". The Journal of Finance, 51 (1), 1809-1833.

Hausman, J.A., 1978. "Specification tests in econometrics". Econometrica, 46 (6), 1251-1271.

Jensen, M., 1986. "Agency cost of free cash flow, corporate finance and takeovers". American Economic Review, 76 (2), 323-329.

Jun, S.G. and F.C. Jen, 2003. "Trade-off model on debt maturity structure". Review of Quantitative Finance and Accounting, 20 (1), 5-34.

Kane, A., A.J. Marcus and R.L. McDonald, 1985. "Debt policy and the rate of return premium to leverage". Journal of Financial and Quantitative Analysis, 20, 479-499.

Kim, C.S., D.C. Mauer and M.H. Stohs, 1995. "Corporate debt maturity policy and investor tax-timing options: theory and evidence". Financial Management, $24,33-45$.

Lewis, C.M., 1990. "A multi-period theory of corporate financial policy under taxation". Journal of Financial and Quantitative Analysis, 25 (1), 25-43.

López-Gracia, J. and R. Mestre-Barberá, 2011. "Tax effect on Spanish SME optimum debt maturity structure". Journal of Business Research, 64, 649-655.

Myers, S.C., 1977. "Determinants of corporate borrowing". Journal of Financial Economics, 5 (2), 147-175.

Ozkan, A., 2000. "Determinants of capital structure and adjustment to long run target: Evidence from UK company panel data". Journal of Business, Finance \& Accounting, 28 (1), 175-198.

Scherr, F.C. and H.M. Hulburt, 2001. "The debt maturity structure of small firms", Financial Management, 30 (1), 85-111.

Smith, C.W. and J.B. Warner, 1979. "On financial contracting. An analysis of bond covenants". Journal of Financial Economics, 7, 117-161.

Stohs, M.H. and D.C. Mauer, 1996. "The determinants of corporate debt maturity structure". Journal of Business, 69, 279-312.

Titman, S. and R. Wessels, 1988. "The determinants of capital structures choice". The Journal of Finance, 43, 1-19.

Whited, T.M., 1992. "Debt, liquidity constraints, and corporate investment: evidence from panel data". The Journal of Finance, 47, 1425-1460. 


\section{Table 1. Descriptive Statistics}

The table presents the mean values of the dependent and independent variables. TOTAL DEBT is the ratio of total debt (short and long-term debt) divided by total assets. DEBT MAT is the percentage of the firm's total debt (long-term debt plus debt in current liabilities) that has a maturity of more than one year. SALES GROWTH is the ratio of current sales divided by prior sales. ASSET GROWTH is the ratio of current assets divided by prior assets. DEPREC_TA is the ratio of depreciation to total assets. LNASSETS is the natural logarithm of firm assets in constant 1995 thousands of euros. DEFAULT RISK is Altman's Z score. PPE_DEPREC is the ratio between property, plant and equipment and annual depreciation. TERM PREMIUM is the difference between the month-end yield on ten-year government bonds and the monthend yield on six-month government bonds. TAX EXP is the ratio of income tax expense to total assets. Firms have been split into small, medium-sized and large enterprises applying the criteria of firm size defined by the European Union in the Commission Recommendation of $3^{\text {rd }}$ April 1996 (96/280/EC).

\begin{tabular}{|l|c|c|c|c|}
\hline & Total sample & Small firms & Medium firms & Large firms \\
\hline TOTAL DEBT (\%) & 63.95 & 63.93 & 63.90 & 64.51 \\
\hline DEBT MAT (\%) & 23.49 & 25.09 & 20.66 & 19.93 \\
\hline SALES GROWTH (\%) & 121.71 & 24.67 & 42.77 & $1,589.56$ \\
\hline ASSET GROWTH (\%) & 440.81 & 18.05 & 102.27 & $7,064.51$ \\
\hline DEPREC_TA (\%) & 4.53 & 4.66 & 4.29 & 4.44 \\
\hline LN ASSETS & 8.01 & 7.37 & 8.92 & 10.60 \\
\hline DEFAULT RISK & 2.58 & 2.64 & 2.46 & 2.47 \\
\hline PPE_DEP & 18.34 & 16.49 & 22.56 & 17.22 \\
\hline TERM PREMIUM (\%) & 1.30 & 1.30 & 1.30 & 1.28 \\
\hline TAX EXP (\%) & 1.48 & 1.38 & 1.64 & 1.68 \\
\hline No. of observations & 246,344 & 159,408 & 73,354 & 13,582 \\
\hline
\end{tabular}




\section{Table 2. Debt maturity, default risk, and firm size}

The table presents the mean values of debt maturity according to various ranges of Altman's Z score. TOTALDEBT is the ratio of total debt (short and long-term debt) divided by total assets. DEBTMAT is the percentage of the firm's total debt (long-term debt plus debt in current liabilities) that has a maturity of more than one year. PROFITABILITY is measured as earnings before interest and taxes plus depreciation expenses divided by total assets. Altman's Z (1968) is the measure of default risk and is calculated according to Equation [1]. Firms have been split into small, medium-sized and large enterprises applying the criteria of firm size defined by the European Union in the Commission Recommendation of $3^{\text {rd }}$ April 1996 (96/280/EC).

\begin{tabular}{|c|c|c|c|c|c|c|c|c|c|}
\hline & $Z<0$ & $0 \leq Z<1$ & $1 \leq Z<2$ & $2 \leq Z<3$ & $3 \leq Z<4$ & $4 \leq Z<5$ & $5 \leq Z<6$ & $6 \leq Z<7$ & $\mathrm{Z} \geq 7$ \\
\hline \multicolumn{10}{|c|}{ Panel A: Total sample } \\
\hline DEBTMAT $(\%)$ & 31.59 & 39.00 & 28.55 & 20.78 & 16.62 & 15.05 & 14.83 & 15.13 & 18.28 \\
\hline TOTALDEBT (\%) & 121.96 & 80.38 & 71.82 & 62.32 & 52.74 & 46.71 & 43.94 & 42.77 & 35.26 \\
\hline PROFITABILITY (\%) & -24.22 & 3.06 & 8.08 & 11.15 & 14.22 & 16.49 & 17.45 & 18.16 & 19.82 \\
\hline No. of observations & 4,889 & 22,232 & 70,597 & 75,610 & 42,254 & 17,244 & 6,606 & 2,861 & 4,051 \\
\hline \multicolumn{10}{|l|}{ Panel B: Small firms } \\
\hline DEBTMAT (\%) & 32.41 & 39.73 & 30.93 & 22.39 & 17.91 & 16.91 & 17.08 & 17.02 & 20.18 \\
\hline TOTALDEBT (\%) & 126.49 & 80.63 & 71.85 & 62.49 & 52.78 & 46.62 & 43.69 & 43.63 & 35.44 \\
\hline PROFITABILITY (\%) & -25.27 & 2.92 & 8.21 & 11.06 & 13.99 & 16.25 & 16.94 & 17.82 & 19.71 \\
\hline No. of observations & 3,262 & 14,450 & 43,922 & 48,935 & 28,368 & 11,247 & 4,302 & 1,907 & 3,015 \\
\hline \multicolumn{10}{|c|}{ Panel C: Medium firms } \\
\hline DEBTMAT (\%) & 29.61 & 37.88 & 24.55 & 17.86 & 14.40 & 12.00 & 10.77 & 11.43 & 13.18 \\
\hline TOTALDEBT (\%) & 114.35 & 79.78 & 71.80 & 61.98 & 52.18 & 46.39 & 43.57 & 40.04 & 33.75 \\
\hline PROFITABILITY (\%) & -21.95 & 3.27 & 7.96 & 11.25 & 14.58 & 16.59 & 17.99 & 18.41 & 21.35 \\
\hline No. of observations & 1,361 & 6,450 & 22,696 & 22,785 & 11,501 & 4,937 & 1,911 & 818 & 895 \\
\hline \multicolumn{10}{|l|}{ Panel D: Large firms } \\
\hline DEBTMAT (\%) & 31.72 & 36.12 & 25.11 & 17.64 & 12.01 & 9.54 & 9.97 & 11.06 & 9.97 \\
\hline TOTALDEBT (\%) & 105.47 & 80.60 & 71.61 & 62.10 & 54.97 & 49.04 & 48.38 & 47.19 & 41.17 \\
\hline PROFITABILITY (\%) & -23.03 & 3.61 & 7.38 & 11.61 & 15.28 & 18.57 & 20.40 & 21.42 & 12.36 \\
\hline No. of observations & 266 & 1,332 & 3,979 & 3,890 & 2,385 & 1,060 & 393 & 136 & 141 \\
\hline
\end{tabular}




\section{Table 3. Correlations}

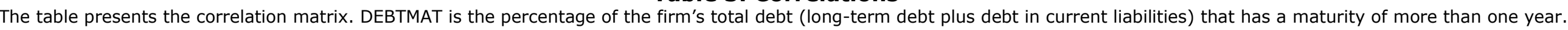

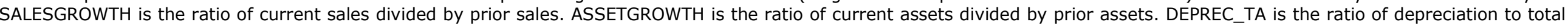

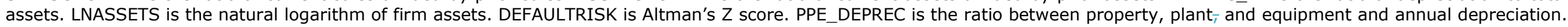

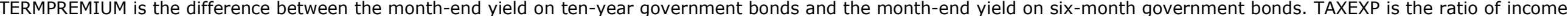
tax expense to total assets.

\begin{tabular}{|c|c|c|c|c|c|c|c|c|}
\hline & DEBTMAT & SALESGROWTH & ASSETGROWTH & DEPREC_TA & LNASSETS & DEFAULTRISK & PPE_DEP & TERMPREMIUM \\
\hline SALESGROWTH & $\begin{array}{l}0.0041 * \\
(0.0565)\end{array}$ & & & & & & & \\
\hline ASSETGROWTH & $\begin{array}{c}0.0089 * * * \\
(0.0000)\end{array}$ & $\begin{array}{c}0.9715 * * * \\
(0.0000)\end{array}$ & & & & & & \\
\hline DEPREC_TA & $\begin{array}{c}0.1563 * * * \\
(0.0000)\end{array}$ & $\begin{array}{l}-0.0005 \\
(0.8320)\end{array}$ & $\begin{array}{c}0.0032 \\
(0.1197)\end{array}$ & & & & & \\
\hline LNASSETS & $\begin{array}{c}-0.0026 * * * \\
(0.1962)\end{array}$ & $\begin{array}{c}0.0092 * * * \\
(0.0000)\end{array}$ & $\begin{array}{c}0.0202 * * * \\
(0.0000)\end{array}$ & $\begin{array}{c}-0.1089 * * * \\
(0.0000)\end{array}$ & & & & \\
\hline DEFAULTRISK & $\begin{array}{c}-0.0331 * * * \\
(0.0000)\end{array}$ & $\begin{array}{l}-0.0005 \\
(0.8292)\end{array}$ & $\begin{array}{l}-0.0009 \\
(0.6651)\end{array}$ & $\begin{array}{c}-0.0478^{* * *} \\
(0.0000)\end{array}$ & $\begin{array}{c}-0.0244 * * * \\
(0.0000)\end{array}$ & & & \\
\hline PPE_DEP & $\begin{array}{c}0.0234 * * * \\
(0.0000)\end{array}$ & $\begin{array}{c}0.0006 \\
(0.7753)\end{array}$ & $\begin{array}{c}0.0017 \\
(0.4209)\end{array}$ & $\begin{array}{c}-0.0184 * * * \\
(0.0000)\end{array}$ & $\begin{array}{c}0.0348 * * * \\
(0.0000)\end{array}$ & $\begin{array}{l}-0.0017 \\
(0.4059)\end{array}$ & & \\
\hline TERMPREMIUM & $\begin{array}{c}-0.0056 * * * \\
(0.0055)\end{array}$ & $\begin{array}{l}-0.0007 \\
(0.7609)\end{array}$ & $\begin{array}{c}0.0028 \\
(0.1720)\end{array}$ & $\begin{array}{c}0.0231 * * * \\
(0.0000)\end{array}$ & $\begin{array}{c}0.0024 \\
(0.2402)\end{array}$ & $\begin{array}{c}0.0016 \\
(0.4243)\end{array}$ & $\begin{array}{c}0.0007 \\
(0.7237)\end{array}$ & \\
\hline TAXEXP & $\begin{array}{c}-0.1255^{* * *} \\
(0.0000)\end{array}$ & $\begin{array}{l}-0.0007 \\
(0.7553)\end{array}$ & $\begin{array}{c}-0.0018 \\
(0.3872)\end{array}$ & $\begin{array}{c}0.0503 * * * \\
(0.0000)\end{array}$ & $\begin{array}{c}0.0232 * * * \\
(0.0000)\end{array}$ & $\begin{array}{c}0.0769 * * * \\
(0.0000)\end{array}$ & $\begin{array}{c}-0.0048 * * \\
(0.0163)\end{array}$ & $\begin{array}{c}0.0054 * * * \\
(0.0067)\end{array}$ \\
\hline
\end{tabular}


Table 4. Determinants of firm debt maturity

Regressions are estimated using panel data. The dependent variable (DEBTMAT) is the percentage of the firm's total debt (long-term debt plus debt in current liabilities) that has a maturity of more than one year. SALESGROWTH is the ratio of current sales divided by prior sales. ASSETGROWTH is the ratio of current assets divided by prior assets. DEPREC_TA is the ratio of depreciation to total assets. LN_ASSETS is the natural logarithm of firm assets in constant 1995 thousands of euros. DEFAULTRISK is Altman's $Z$ score. HIGHDEFAULT is a dummy variable that equals one if the firm has a negative value for Altman's Z score, and zero otherwise. LOWDEFAULT is a dummy variable that equals one if Altman's Z score is above the $66^{\text {th }}$ percentile, and zero otherwise. PPE_DEPREC is the ratio between property, plant and equipment and annual depreciation. TERMPREMIUM is the difference between the month-end yield on ten-year government bonds and the month-end yield on six-month government bonds. TAXEXP is the ratio of income tax expense to total assets. T-statistics are in parentheses. $* * *, * *$ and $*$ represent significance at the $1 \%, 5 \%$ and $10 \%$ levels, respectively.

\begin{tabular}{|c|c|c|c|c|c|c|c|}
\hline & $\begin{array}{l}\text { Expected } \\
\text { sign }\end{array}$ & (1) & (2) & (3) & (4) & (5) & (6) \\
\hline Intercept & & $\begin{array}{c}-0.3797 * * * \\
(-40.85)\end{array}$ & $\begin{array}{c}-0.2506 * * * \\
(-28.74)\end{array}$ & $\begin{array}{c}-0.2441 * * * \\
(-31.75)\end{array}$ & $\begin{array}{c}-0.2832 * * * \\
(-29.85)\end{array}$ & $\begin{array}{c}-0.1657 * * * \\
(-18.75)\end{array}$ & $\begin{array}{c}-0.1613 * * * \\
(-20.67)\end{array}$ \\
\hline SALES GROWTH & - & $\begin{array}{l}0.0000 \\
(0.68)\end{array}$ & & & $\begin{array}{l}0.0000 \\
(0.68)\end{array}$ & & \\
\hline ASSET GROWTH & - & & $\begin{array}{l}0.0000 \\
(0.21)\end{array}$ & & & $\begin{array}{l}0.0000 \\
(0.22)\end{array}$ & \\
\hline DEPREC_TA & + & & & $\begin{array}{c}0.0769 * * * \\
\quad(8.04)\end{array}$ & & & $\begin{array}{c}0.0819 * * * \\
(8.62)\end{array}$ \\
\hline LNASSETS & + & $\begin{array}{c}0.0753 * * * \\
(67.32)\end{array}$ & $\begin{array}{c}0.0711 * * * \\
(67.90)\end{array}$ & $\begin{array}{c}0.0696 * * * \\
(69.02)\end{array}$ & $\begin{array}{c}0.0649 * * * \\
(57.13)\end{array}$ & $\begin{array}{c}0.0607 * * * \\
(57.17)\end{array}$ & $\begin{array}{c}0.0596 * * * \\
(58.35)\end{array}$ \\
\hline DEFAULT RISK & - & $\begin{array}{c}0.0002 * * * \\
(3.67)\end{array}$ & $\begin{array}{c}0.0001 * * \\
(2.40)\end{array}$ & $\begin{array}{c}0.0001^{* *} \\
(2.24)\end{array}$ & & & \\
\hline HIGH DEFAULT & - & & & & $\begin{array}{c}-0.0391 * * * \\
(-12.60)\end{array}$ & $\begin{array}{c}-0.0405 * * * \\
(-14.06)\end{array}$ & $\begin{array}{c}-0.0427 * * * \\
(-15.45)\end{array}$ \\
\hline LOW DEFAULT & - & & & & $\begin{array}{c}-0.0467 * * * \\
(-42.39)\end{array}$ & $\begin{array}{c}-0.0491 * * * \\
(-46.30)\end{array}$ & $\begin{array}{c}-0.0493 * * * \\
(-47.89)\end{array}$ \\
\hline PPE_DEP & + & $\begin{array}{c}0.0000 * * * \\
(2.62)\end{array}$ & $\begin{array}{c}0.0000 * * \\
(2.54)\end{array}$ & $\begin{array}{c}0.0000 * * * \\
(2.81)\end{array}$ & $\begin{array}{c}0.0000 * * * \\
(2.60)\end{array}$ & $\begin{array}{l}0.0000 * * \\
(2.50)\end{array}$ & $\begin{array}{c}0.0000 * * * \\
(2.78)\end{array}$ \\
\hline TERM PREMIUM & + & $\begin{array}{c}0.0025^{* * *} * \\
(4.31)\end{array}$ & $\begin{array}{c}-0.0393 * * * \\
(-19.00)\end{array}$ & $\begin{array}{c}-0.0378^{* * *} \\
(-28.67)\end{array}$ & $\begin{array}{c}0.0022 * * * \\
(3.80)\end{array}$ & $\begin{array}{c}-0.0342 * * * \\
(-16.62)\end{array}$ & $\begin{array}{c}-0.0331 * * * \\
(-25.20)\end{array}$ \\
\hline TAX EXP & - & $\begin{array}{c}-0.6534 * * * \\
(-43.27)\end{array}$ & $\begin{array}{c}-0.5259 * * * \\
(-40.57)\end{array}$ & $\begin{array}{c}-0.5441 * * * \\
(-42.74)\end{array}$ & $\begin{array}{c}-0.4992 * * * \\
(-32.01)\end{array}$ & $\begin{array}{c}-0.3964 * * * \\
(-29.82)\end{array}$ & $\begin{array}{c}-0.4116 * * * \\
(-31.50)\end{array}$ \\
\hline Hausman test & & $3,051.59 * * *$ & $4,475.22 * * *$ & $4,790.80 * * *$ & $2,011.55^{* * *}$ & $3,720.56 * * *$ & $4,441.07 * * *$ \\
\hline$F$ test & & $426.30 * * *$ & $392.71 * * *$ & $415.64 * * *$ & $524.60 * * *$ & $510.14 * * *$ & $543.05 * * *$ \\
\hline \# observations & & 214,830 & 232,024 & 246,344 & 214,830 & 232,024 & 246,344 \\
\hline \# firms & & 37,442 & 39,196 & 39,603 & 37,442 & 39,196 & 39,603 \\
\hline
\end{tabular}


Table 5. Determinants of firm debt maturity according to size

Regressions are estimated using panel data. The dependent variable (DEBTMAT) is the percentage of the firm's total debt (long-term debt plus debt in current liabilities) that has a maturity of more than one year. SALESGROWTH is the ratio of current sales divided by prior sales. ASSETGROWTH is the ratio of current assets divided by prior assets. DEPREC TA is the ratio of depreciation to total assets. LNASSETS is the natural logarithm of firm assets in constant 1995 thousands of euros. HIGHDEFAULT is a dummy variable that equals one if the firm has a negative value for Altman's Z score, and zero otherwise. LOWDEFAULT is a dummy variable that equals one if Altman's Z score is above the $66^{\text {th }}$ percentile, and zero otherwise. PPE DEPREC is the ratio between property, plant and equipment and annual depreciation. TERMPREMIUM is the score is above the $66^{\text {th }}$ percentile, and zero otherwise. PPE_DEPREC is the ratio between property, plant ${ }_{\bar{\gamma}}$ and equipment and annual depreciation. TERMPREMIUM is the
difference between the month-end yield on ten-year government bonds and the month-end yield on six-month government bonds. TAXEXP is the ratio of income tax expense to total assets. Firms have been split into small, medium-sized and large enterprises applying the criteria of firm size defined by the European Union in the Commission Recommendation of $3^{\text {rd }}$ April 1996 (96/280/EC). T-statistics are in parentheses. $* * * * *$ and $*$ represent significance at the $1 \%$, 5\% and $10 \%$ levels, respectively.

\begin{tabular}{|c|c|c|c|c|c|c|c|c|c|c|}
\hline & \multicolumn{4}{|c|}{ SMALL } & \multicolumn{3}{|c|}{ MEDIUM } & \multicolumn{3}{|c|}{ LARGE } \\
\hline & $\begin{array}{l}\text { Expected } \\
\text { sign }\end{array}$ & (1) & (2) & (3) & (4) & (5) & (6) & $\begin{array}{l}7) \\
\end{array}$ & (8) & (9) \\
\hline $\begin{array}{l}\text { Intercept } \\
\text { SALES GROWTH }\end{array}$ & . & $\begin{array}{c}-0.3766 * * * \\
(-30.82) \\
-0.0000\end{array}$ & $\begin{array}{c}-0.2365^{* * *} * \\
(-20.55)\end{array}$ & $\begin{array}{c}-0.2366 * * * \\
(-23.29)\end{array}$ & $\begin{array}{c}-0.3528^{* * *} \\
(-19.08) \\
0.0000\end{array}$ & $\begin{array}{c}-0.2775 * * * \\
(-15.92)\end{array}$ & $\begin{array}{c}-0.3019 * * * \\
(-18.19)\end{array}$ & $\begin{array}{c}-0.5909 * * * \\
(-12.20) \\
0.0000\end{array}$ & $\begin{array}{c}-0.5110 * * * \\
(-11.51)\end{array}$ & $\begin{array}{c}-0.4937 * * * \\
(-11.59)\end{array}$ \\
\hline ASSET GROWTH & - & & $\begin{array}{c}-0.0002 \\
(-0.76)\end{array}$ & & & $\begin{array}{l}0.0000 \\
(1.23)\end{array}$ & & & $\begin{array}{l}0.0000 \\
(0.23)\end{array}$ & \\
\hline DEPREC_TA & + & & & $\begin{array}{l}0.0916 * * * \\
(8.83)\end{array}$ & & & $\begin{array}{c}0.1451 * * * \\
(5.46)\end{array}$ & & & $\begin{array}{l}0.0694 \\
(1.24)\end{array}$ \\
\hline LNASSETS & + & $\begin{array}{c}0.0853 * * * \\
(53.28)\end{array}$ & $\begin{array}{c}0.0795 * * * \\
(53.29)\end{array}$ & $\begin{array}{c}0.0782 * * * \\
(54.45)\end{array}$ & $\begin{array}{c}0.0631 * * * \\
(31.38)\end{array}$ & $\begin{array}{c}0.0625 * * * \\
(32.31)\end{array}$ & $\begin{array}{c}0.0648 * * * \\
(33.67)\end{array}$ & $\begin{array}{c}0.0746 * * * \\
(16.80)\end{array}$ & $\begin{array}{c}0.0748^{* * *} \\
(17.45)\end{array}$ & $\begin{array}{c}0.0737 * * * \\
(17.40)\end{array}$ \\
\hline HIGH DEFAULT & - & $\begin{array}{c}-0.0521^{* * *} \\
(-13.01)\end{array}$ & $\begin{array}{c}-0.0491 * * * \\
(-13.28)\end{array}$ & $\begin{array}{c}-0.0530 * * * \\
(-14.98)\end{array}$ & $\begin{array}{c}-0.0424 * * * \\
(-8.43)\end{array}$ & $\begin{array}{c}-0.0451 * * * \\
(-9.34)\end{array}$ & $\begin{array}{c}-0.0470 * * * \\
(-10.00)\end{array}$ & $\begin{array}{c}-0.0619 * * * \\
(-5.52)\end{array}$ & $\begin{array}{c}-0.0602 * * * \\
(-5.55)\end{array}$ & $\begin{array}{c}-0.0540 * * * \\
(-5.04)\end{array}$ \\
\hline LOW DEFAULT & - & $\begin{array}{c}-0.0398 * * * \\
(-28.73)\end{array}$ & $\begin{array}{c}-0.0439 * * * \\
(-33.21)\end{array}$ & $\begin{array}{c}-0.0439 * * * \\
(-34.29)\end{array}$ & $\begin{array}{c}-0.0488 * * * \\
(-26.54)\end{array}$ & $\begin{array}{c}-0.0487 * * * \\
(-26.98)\end{array}$ & $\begin{array}{c}-0.0486 * * * \\
(-27.45)\end{array}$ & $\begin{array}{c}-0.0471 * * * \\
(-10.94)\end{array}$ & $\begin{array}{c}-0.0482 * * * \\
(-11.37)\end{array}$ & $\begin{array}{c}-0.0489 * * * \\
(-11.72)\end{array}$ \\
\hline PPE_DEP & + & $\begin{array}{c}0.0001^{* * *} \\
(8.82)\end{array}$ & $\begin{array}{l}0.0000 \\
(1.56)\end{array}$ & $\begin{array}{c}0.0000 * * \\
(2.17)\end{array}$ & $\begin{array}{l}0.0000 \\
(1.37)\end{array}$ & $\begin{array}{l}0.0000 \\
(1.01)\end{array}$ & $\begin{array}{l}0.0000 \\
(0.97)\end{array}$ & $\begin{array}{l}0.0000 \\
(0.28)\end{array}$ & $\begin{array}{l}0.0000 \\
(1.52)\end{array}$ & $\begin{array}{c}0.0000^{* *} \\
(2.05)\end{array}$ \\
\hline TERM PREMIUM & + & $\begin{array}{l}0.0009 \\
(1.21)\end{array}$ & $\begin{array}{c}-0.0417^{* * *} \\
(-15.73)\end{array}$ & $\begin{array}{c}-0.0386 * * * \\
(-23.26)\end{array}$ & $\begin{array}{c}0.0040 * * * \\
(4.55)\end{array}$ & $\begin{array}{c}-0.0266 * * * \\
(-7.89)\end{array}$ & $\begin{array}{c}-0.0277 * * * \\
(-12.57)\end{array}$ & $\begin{array}{c}0.0046^{* *} \\
(2.27)\end{array}$ & $\begin{array}{c}-0.0309 * * * \\
(-4.01)\end{array}$ & $\begin{array}{c}-0.0351 * * * \\
(-6.63)\end{array}$ \\
\hline TAX EXP & - & $\begin{array}{c}-0.5474 * * * \\
(-26.33)\end{array}$ & $\begin{array}{c}-0.3710^{* * *} \\
(-22.75)\end{array}$ & $\begin{array}{c}-0.3874 * * * \\
(-24.14)\end{array}$ & $\begin{array}{c}-0.4167 * * * \\
(-17.51)\end{array}$ & $\begin{array}{c}-0.4078 * * * \\
(-17.48)\end{array}$ & $\begin{array}{c}-0.4210^{* * *} \\
(-18.25) \\
\end{array}$ & $\begin{array}{c}-0.3626 * * * \\
(-6.54) \\
\end{array}$ & $\begin{array}{c}-0.3695 * * * \\
(-6.76)\end{array}$ & $\begin{array}{c}-0.3767 * * * \\
(-6.98) \\
\end{array}$ \\
\hline Hausman test & & $1,489.02 * * *$ & $1,878.11^{* * *}$ & $2,354.12 * * *$ & $594.08^{* * *}$ & $683.72 * * *$ & $1,013.67 * * *$ & $240.44 * * *$ & $194.64 * * *$ & $50.51 * * *$ \\
\hline $\mathrm{F}$ test & & $381.41 * * *$ & $361.24 * * *$ & $382.54 * * *$ & $172.08 * * *$ & $169.00 * * *$ & $180.83 * * *$ & $37.58 * * *$ & $38.00 * * *$ & $38.81 * * *$ \\
\hline \# observations & & 135,754 & 148,778 & 159,408 & 66,524 & 70,166 & 73,358 & 12,552 & 13,082 & 13,582 \\
\hline \# firms & & 28,059 & 30,183 & 30,861 & 14,679 & 15,246 & 15,457 & 2,717 & 2,790 & 2,823 \\
\hline
\end{tabular}


Table 6. Determinants of firm debt maturity according to size

Regressions are estimated using panel data. The dependent variable (DEBTMAT) is the percentage of the firm's total debt (long-term debt plus debt in current liabilities) that has a maturity of more than one year. SALESGROWTH is the ratio of current sales divided by prior sales. ASSETGROWTH is the ratio of current assets divided by prior assets. DEPREC_TA is the ratio of depreciation to total assets. LNASSETS is the natural logarithm of firm assets in constant 1995 thousands of euros. HIGHDEFAULT is a dummy variable that equals one if the firm has a negative value for Altman's $Z$ score, and zero otherwise. LOWDEFAULT is a dummy variable that equals one if Altman's $Z$ score is above the $66^{\text {th }}$ percentile, and zero otherwise. PPE_DEPREC is the ratio between property, plant and equipment and annual depreciation. TERMPREMIUM is the difference between the month-end yield on ten-year government bonds and the month-end yield on six-month government bonds. TAXEXP is the ratio of income tax expense to total assets. Firms have been split into small, medium-sized and large enterprises applying the criteria of firm size defined by the European Union in the Commission Recommendation of $3^{\text {rd }}$ April $1996(96 / 280 / E C)$. T-statistics are in parentheses. $* * *, * *$ and $*$ represent significance at the $1 \%, 5 \%$ and $10 \%$ levels, respectively.

\begin{tabular}{|c|c|c|c|c|c|c|}
\hline & (1) & (2) & (3) & (4) & (5) & (6) \\
\hline $\begin{array}{l}\text { Intercept } \\
\text { SALES GROWTH }\end{array}$ & $\begin{array}{c}-0.2991 * * * \\
(-31.21) \\
0.0000 \\
(0.67)\end{array}$ & $\begin{array}{c}-0.1864 * * * \\
(-20.82)\end{array}$ & $\begin{array}{c}-0.1862 * * * \\
(-23.44)\end{array}$ & $\begin{array}{c}-0.2871 * * * \\
(-30.13) \\
0.0000 \\
(0.68)\end{array}$ & $\begin{array}{c}-0.1698^{* * *} \\
(-19.12)\end{array}$ & $\begin{array}{c}-0.1664 * * * \\
(-21.18)\end{array}$ \\
\hline ASSET GROWTH & & $\begin{array}{l}0.0000 \\
(0.23)\end{array}$ & & & $\begin{array}{l}0.0000 \\
(0.13)\end{array}$ & \\
\hline DEPREC_TA & & & $\begin{array}{c}-0.0507 * * \\
(-2.59)\end{array}$ & & & $\begin{array}{l}-0.0371 \\
(-0.86)\end{array}$ \\
\hline LNASSETS & $\begin{array}{l}0.0668 * * * \\
(58.15)\end{array}$ & $\begin{array}{l}0.0632 * * * \\
(58.73)\end{array}$ & $\begin{array}{c}0.0627 * * * \\
(60.44)\end{array}$ & $\begin{array}{c}0.0654 * * * \\
(57.30)\end{array}$ & $\begin{array}{c}0.0612 * * * \\
(57.35)\end{array}$ & $\begin{array}{c}0.0602 * * * \\
(58.62)\end{array}$ \\
\hline HIGH DEFAULT & $\begin{array}{c}-0.0524 * * * \\
(-10.49)\end{array}$ & $\begin{array}{c}-0.0558^{* * *} * \\
(-11.79)\end{array}$ & $\begin{array}{c}-0.0509 * * * \\
(-11.04)\end{array}$ & $\begin{array}{c}-0.0588 * * * \\
(-4.87)\end{array}$ & $\begin{array}{c}-0.0588 * * * \\
(-5.07)\end{array}$ & $\begin{array}{c}-0.0461 * * * \\
(-4.04)\end{array}$ \\
\hline LOW DEFAULT & $\begin{array}{c}-0.0522 * * * \\
(-29.70)\end{array}$ & $\begin{array}{c}-0.0528^{* * *} \\
(-30.75)\end{array}$ & $\begin{array}{c}-0.0521 * * * \\
(-30.94)\end{array}$ & $\begin{array}{c}-0.0539 * * * \\
(-12.64)\end{array}$ & $\begin{array}{c}-0.0555 * * * \\
(-13.31)\end{array}$ & $\begin{array}{c}-0.0551 * * * \\
(-13.37)\end{array}$ \\
\hline PPE_DEP & $\begin{array}{c}0.0000 * * \\
(2.45)\end{array}$ & $\begin{array}{c}0.0000^{*} \\
(1.95)\end{array}$ & $\begin{array}{c}0.0000 * * \\
(2.10)\end{array}$ & $\begin{array}{l}-0.0000 \\
(-1.52)\end{array}$ & $\begin{array}{c}-0.0000 \\
(-0.48)\end{array}$ & $\begin{array}{l}-0.0000 \\
(-0.47)\end{array}$ \\
\hline TERM PREMIUM & $\begin{array}{c}-0.0019 * * * \\
(-2.67)\end{array}$ & $\begin{array}{c}-0.0383^{* * *} * \\
(-18.21)\end{array}$ & $\begin{array}{c}-0.0361^{* * *} \\
(-25.86)\end{array}$ & $\begin{array}{c}-0.0027^{*} \\
(-1.77)\end{array}$ & $\begin{array}{c}-0.0387 * * * \\
(-15.60)\end{array}$ & $\begin{array}{c}-0.0366 * * * \\
(-18.38)\end{array}$ \\
\hline TAX EXP & $\begin{array}{c}-0.4965^{* * *} \\
(-21.56)\end{array}$ & $\begin{array}{c}-0.4829 * * * \\
(-21.47)\end{array}$ & $\begin{array}{c}-0.4856 * * * \\
(-21.92)\end{array}$ & $\begin{array}{c}-0.4481 * * * \\
(-7.96)\end{array}$ & $\begin{array}{c}-0.4425 * * * \\
(-8.04)\end{array}$ & $\begin{array}{c}-0.4401 * * * \\
(-8.10)\end{array}$ \\
\hline SMALL*SALES GROWTH & $\begin{array}{l}-0.0000 \\
(-0.10)\end{array}$ & & & $\begin{array}{l}-0.0000 \\
(-0.71)\end{array}$ & & \\
\hline SMALL*ASSET GROWTH & & $\begin{array}{l}0.0001 \\
(1.34)\end{array}$ & & & $\begin{array}{l}0.0000 \\
(1.20)\end{array}$ & \\
\hline SMALL*DEPREC_TA & & & $\begin{array}{c}0.1600 * * * \\
(7.99)\end{array}$ & & & $\begin{array}{c}0.1232 * * * \\
(2.85)\end{array}$ \\
\hline SMALL*HIGH DEFAULT & $\begin{array}{l}0.0200 * * * \\
(3.28)\end{array}$ & $\begin{array}{c}0.0226 * * * \\
(3.98)\end{array}$ & $\begin{array}{c}0.0114^{* *} \\
(2.07)\end{array}$ & $\begin{array}{c}0.0210 * \\
(1.69)\end{array}$ & $\begin{array}{l}0.0193 \\
(1.62)\end{array}$ & $\begin{array}{l}0.0036 \\
(0.30)\end{array}$ \\
\hline SMALL*LOW DEFAULT & $\begin{array}{l}0.0086 * * * \\
(4.18)\end{array}$ & $\begin{array}{c}0.0062 * * * \\
(3.08)\end{array}$ & $\begin{array}{c}0.0050 * * * \\
(2.57)\end{array}$ & $\begin{array}{c}0.0076^{*} \\
(1.75)\end{array}$ & $\begin{array}{l}0.0069 \\
(1.63)\end{array}$ & $\begin{array}{l}0.0063 \\
(1.50)\end{array}$ \\
\hline SMALL*PPE_DEP & $\begin{array}{c}0.0001 * * * \\
(8.71)\end{array}$ & $\begin{array}{l}0.0000 \\
(1.41)\end{array}$ & $\begin{array}{c}0.0000 * \\
(1.65)\end{array}$ & $\begin{array}{c}0.0000^{*} \\
(1.69)\end{array}$ & $\begin{array}{l}0.0000 \\
(0.64)\end{array}$ & $\begin{array}{l}0.0000 \\
(0.65)\end{array}$ \\
\hline SMALL*TERM PREMIUM & $\begin{array}{c}0.0066 * * * \\
(8.95)\end{array}$ & $\begin{array}{c}0.0071^{* * * *} \\
(9.85)\end{array}$ & $\begin{array}{c}0.059 * * * \\
(7.69)\end{array}$ & $\begin{array}{c}0.0052 * * * \\
(3.44)\end{array}$ & $\begin{array}{c}0.0048^{* * * *} \\
(3.25)\end{array}$ & $\begin{array}{c}0.037 * * \\
(2.31)\end{array}$ \\
\hline SMALL*TAX EXP & $\begin{array}{l}0.0026 \\
(0.09) \\
\end{array}$ & $\begin{array}{c}0.1308 * * * \\
(4.93)\end{array}$ & $\begin{array}{c}0.1131 * * * \\
(4.33)\end{array}$ & $\begin{array}{c}-0.0548 \\
(-0.95)\end{array}$ & $\begin{array}{l}0.0484 \\
(0.86)\end{array}$ & $\begin{array}{l}0.0299 \\
(0.54)\end{array}$ \\
\hline Hausman test & $3,587.06 * * *$ & $3,980.28 * * *$ & $5,215.08 * * *$ & $2,484.51 * * *$ & $3,792.64 * * *$ & $4,535.02 * * *$ \\
\hline$F$ test & $392.19 * * *$ & $386.71 * * *$ & $415.33 * * *$ & $382.67 * * *$ & $378.17 * * *$ & $402.86 * * *$ \\
\hline \# observations & 214,830 & 232,024 & 246,344 & 214,830 & 232,024 & 246,344 \\
\hline \# firms & 37,442 & 39,196 & 39,603 & 37,442 & 39,196 & 39,603 \\
\hline
\end{tabular}

